\title{
Distance to edges, edge contrast and landscape fragmentation: Interactions affecting farmland birds around forest plantations
}

\author{
Luís Reino ${ }^{a, b, c, *}$, Pedro Beja ${ }^{b, d}$, Patrick E. Osborne ${ }^{c}$, Rui Morgado ${ }^{e}$, António Fabião ${ }^{a}$, \\ John T. Rotenberry ${ }^{f}$ \\ ${ }^{a}$ Centro de Estudos Florestais, Dept. Eng. Florestal, Instituto Superior de Agronomia, Universidade Técnica de Lisboa, \\ Tapada da Ajuda, 1349-017 Lisboa, Portugal \\ ${ }^{\mathrm{b}}$ ERENA - Ordenamento e Gestão de Recursos Naturais, Lda., Rua Robalo Gouveia, 1-1A, 1900-392 Lisboa, Portugal \\ ${ }^{c}$ Centre for Environmental Sciences, School of Civil Engineering and the Environment, Univ. of Southampton, Highfield, \\ Southampton SO17 1BJ England, United Kingdom \\ ${ }^{\mathrm{d}}$ CIBIO, Centro de Investigação em Biodiversidade e Recursos Genéticos Campus Agrário de Vairão, Universidade do Porto, \\ 4485-661 Vairão, Portugal \\ eCentro de Ecologia Aplicada "Prof. Baeta Neves", Instituto Superior de Agronomia, Universidade. Técnica de Lisboa, \\ Tapada da Ajuda, 1349-017 Lisboa, Portugal \\ f Department of Biology, Univ. of California, Riverside, CA 92521, USA
}

\section{A R T I C L E I N F O}

\section{Article history:}

Received 8 May 2008

Received in revised form

24 November 2008

Accepted 5 December 2008

Available online 21 January 2009

\section{Keywords:}

Afforestation

Edge effects

Landscape management

Grassland

Mediterranean farmland

Steppe birds

\begin{abstract}
A B S T R A C T
Afforestation often causes direct habitat losses for farmland birds of conservation concern, but it is uncertain whether negative effects also extend significantly into adjacent open land. Information is thus required on how these species react to wooded edges, and how their responses are affected by edge and landscape characteristics. These issues were examined in Mediterranean arable farmland, using bird counts at 0, 100, 200, 300 and $>300 \mathrm{~m}$ from oak, pine and eucalyptus edges, embedded in landscapes with variable amounts and spatial configurations of forest plantations. Bird diversity declined away from edges, including that of woodland, farmland and ground-nesting birds. Positive edge responses were also found for overall and woodland bird abundances, and for five of the nine most widespread and abundant species (Galerida larks, stonechat, linnet, goldfinch and corn bunting). Strong negative edge effects were only recorded for steppe birds, with reduced abundances near edges of calandra larks and short-toed larks, but not of little bustards and tawny pipits. Edge contrast affected the magnitude of edge effects, with a tendency for stronger responses to old and tall eucalyptus plantations (hard edges) than to young and short oak plantations (soft edges). There were also species-specific interactions between edge and fragmentation effects, with positive edge responses tending to be strongest in less fragmented landscapes, whereas steppe birds tended to increase faster away from edges and to reach the highest species richness and abundances in large arable patches. Results suggest that forest plantations may increase overall bird diversity and abundance in adjacent farmland, at the expenses of steppe birds of conservation concern.
\end{abstract}

\footnotetext{
* Corresponding author: Address: Centro de Estudos Florestais, Dept. Eng. Florestal, Instituto Superior de Agronomia, Universidade Técnica de Lisboa, Tapada da Ajuda, 1349-017 Lisboa, Portugal. Tel.: +351 964515213; fax: +351 219990019.

E-mail address: luisreino@isa.utl.pt (L. Reino).
}

0006-3207/\$ - see front matter @ 2008 Elsevier Ltd. All rights reserved.

doi:10.1016/j.biocon.2008.12.011 
Clustering forest plantations in a few large patches and thus reducing the density of wooded edges at the landscape-scale might reduce such negative impacts.

(c) 2008 Elsevier Ltd. All rights reserved.

\section{Introduction}

Afforestation is a prominent conservation issue in many regions worldwide, especially where forests replace open habitats of conservation significance (Díaz et al., 1998; Shochat et al., 2001; Brennan and Kuvlesky, 2005). Forests are often planted on grassland and shrubland to increase profits from otherwise poorly productive soils, though there may also be conservation objectives such as restoring forest ecosystems in marginal or abandoned farmland (Madsen, 2002; Santos et al., 2006; Lazdinis et al., 2005; Loyn et al., 2007). Climate change has prompted much interest in large-scale afforestation to reduce atmospheric concentrations of carbon dioxide (Potter et al., 2007), raising concerns about potential impacts on biodiversity (Matthews et al., 2002; Caparrós and Jacquemont, 2003; García-Quijano et al., 2007). Information is thus increasingly required on the interrelationships between afforestation and biodiversity, to evaluate environmental costs and benefits of afforestation policies, and to design afforestation programmes with minimal impacts on biodiversity.

The loss of open habitat is the most direct impact of afforestation, causing the replacement of open habitat species by forest species. Although this is positive where the latter are the targets of conservation efforts (Loyn et al., 2007), plantations are often used by generalist and widely distributed species, occupying areas previously inhabited by grassland and shrubland species of conservation concern (Díaz et al., 1998; Shochat et al., 2001). Much less is known about the impacts of afforestation on adjacent open land, though theoretical and empirical evidence suggests that effects may extend well beyond forest boundaries (e.g., Ries et al., 2004; Ewers and Didham, 2006a). These impacts arise due to habitat fragmentation, as continuous patches of open habitat are broken into smaller, isolated patches surrounded by a matrix of forested habitats, increasingly influenced by the proliferation of habitat edges (Ries et al., 2004).

Edge effects may play a critical role in determining impacts of afforestation, mediating landscape-scale changes in species richness, composition and abundances (Ries et al., 2004; Ewers and Didham, 2007). Species characteristic of open habitats are often absent or scarce near wooded boundaries (Coppedge et al., 2004; Fletcher, 2005), and are expected to decline with increasing edge density in smaller and more convoluted patches (Ewers and Didham, 2007). At the same time, however, edges are preferred by a number of other species, which tend to increase in more fragmented landscapes (Söderström and Pärt, 2000; Coppedge et al., 2004). Indeed, habitat edges may actually be richer in species than either of the adjacent habitats, though increases in species richness with distance to edges have also been reported (Ewers and Didham, 2006a). The impacts of afforestation are thus conditional on assemblage composition and on the conservation value of sets of species showing positive and negative responses to edge effects. The magnitude of such impacts depends on the penetration of edge effects into adjacent habitats, which may be greatly affected by changes in edge and landscape features. Edge effects may penetrate more where the contrast between edges and adjacent habitats is high (Ries et al., 2004), and their strength may change with landscape fragmentation, due to the cumulative effects of multiple edges (Fletcher, 2005) and synergistic interactions between edge and patch area effects (Ewers et al., 2007). At present, however, it is largely unknown how open habitat species with different life histories and habitat requirements react to forest plantation edges, and how these responses are affected by edge and landscape characteristics.

We investigated these issues by examining the responses of farmland birds to forest edges in Southern Portugal. In Mediterranean regions, afforestation of marginal agricultural land has increased over the past decades, following a long-term trend of rural depopulation and abandonment of poorly productive soils (Van Doorn and Bakker, 2007). In the European Union, this process accelerated following the implementation of European regulation 2080/92, which provided financial support for afforestation, partly justified by the objective of restoring ancient forest habitats and their associated biodiversity (Robson, 1997). Planted forests, however, seem to be largely inadequate for promoting rich forest bird communities (Díaz et al., 1998), though this depends on forest composition and management (López and Moro, 1997; Santos et al., 2006). Concurrently, plantations have negative impacts by excluding species of high conservation value from the habitats they replace, particularly birds strictly associated with open pastures and dry cereal cropland (Bota et al., 2005). At least some of these bird species avoid or occur at low density in landscapes fragmented by woody habitats (Brotons et al., 2005; Moreira et al., 2005), suggesting that afforestation effects may be far greater than those related to the lost area of open habitat. Here we test this hypothesis by examining how bird assemblages vary with distance to forest edges in terms of: (i) overall species richness and abundance, (ii) richness and abundance of birds grouped according to habitat requirements, and (iii) abundance of the most common species. Subsequently, we investigate how edge and landscape features modify bird responses to edges. This information is then used to discuss the consequences of afforestation for bird conservation in adjacent farmland.

\section{Methods}

\subsection{Study area}

The study was conducted in Southern Portugal, in a farmland landscape mostly included in the Special Protection Area (SPA) of Castro Verde, designated under European Directive 79/409/EEC to protect steppe birds. The climate is Mediterranean, with hot summers (averaging $24^{\circ} \mathrm{C}$ [16-32 $\left.\mathrm{C}\right]$ in July), mild winters $\left(9^{\circ} \mathrm{C}\left[5-14^{\circ} \mathrm{C}\right]\right.$ in January), and $>75 \%$ of annual 
rainfall $(500-600 \mathrm{~mm})$ concentrated in October-March. The landscape is flat or gently undulating (100-300 $\mathrm{m}$ a.s.l.) and dominated by an agricultural mosaic of cereal, fallow and ploughed fields, created by rotational dry cereal cultivation. Until recently, tree cover was largely restricted to some eucalyptus (Eucalyptus sp.) plantations (40-60 years old) and open holm oak (Quercus rotundifolia) woodlands grazed by livestock. Afforestation with umbrella pines (Pinus pinea) and holm and cork oaks (Quercus suber) has increased since the early 1990s due to EU subsidies, mainly in the periphery of the SPA. Details of the study area are reported elsewhere (Moreira, 1999; Delgado and Moreira, 2000; Moreira et al., 2005).

\subsection{Sampling design}

Sampling was carried out on farmland along $300 \mathrm{~m}$ transects perpendicular to the edge of 52 forest patches, representative of the three most common forest plantations in the region (eucalyptus, pine and oak stands). Only fallow fields were sampled, to reduce variation among sites unrelated to edge and landscape features, and because they are particularly important for steppe birds of conservation concern (Delgado and Moreira, 2000). Transect length was limited by the size of fallow fields and forest spatial distribution. To account for the possibility of edge effects penetrating more than $300 \mathrm{~m}$ into farmland habitats, sampling included 28 additional fields at $>300 \mathrm{~m}$ from any forest edge. The selection of sampling sites was based on 1:25,000 land cover maps from 1990 (http://www.igeo.pt/IGEO/portugues/produtos/inf_cartografica.htm), updated through systematic field checking of new forest stands planted up to the beginning of 2005. Degraded and abandoned forest patches with low and irregular tree cover were discarded, because they were not representative of modern forest plantations. However, young plantations $(<1$ year old) were included to assess eventual variation in edge responses with forest age. Each forest plantation was visited and selected for sampling if it was adjacent to a fallow field at least $600 \mathrm{~m}$ long and $300 \mathrm{~m}$ wide, to allow sampling of bird assemblages at least $300 \mathrm{~m}$ from any forest edge. Only one fallow field was sampled per forest patch, independently of its size, to avoid pseudo-replication. All sites meeting these selection conditions were sampled, whereas the sites far from forest edges were randomly selected.

\subsection{Bird data}

Bird sampling was conducted twice (April and May) in the breeding season of 2005. In each of the 52 transects, birds were counted at 0, 100, 200 and $300 \mathrm{~m}$ from the forest edge, using 10minute duration point counts (Bibby et al., 2000). Conversely, only one point was counted in each of the 28 fallow fields at $>$ $300 \mathrm{~m}(1531 \pm 1201 \mathrm{~m}, 310-5000 \mathrm{~m})$ from edges. At each point, all individual birds and flocks of each species were identified and recorded on maps, though records at $>50 \mathrm{~m}$ from the observer were discarded from further analyses. When birds were flushed, care was taken to check if they landed further ahead to minimize double counting errors. Birds flying over but not landing were not counted, except in the case of display flights of territorial species. Due to difficulties in reliably identifying every individual in the field, categorisation to the genus level was made for crested and Thekla larks (Galerida cristata and G. theklae) and for common and Spanish sparrows (Passer domesticus and P. hispaniolensis). Birds were also categorized according to their woodland or farmland affinities. Woodland birds encompassed species potentially benefiting from forest plantations, as they require wooded habitats such as forests, woodlots, orchards and shrubland (e.g., Díaz et al., 1998), whereas farmland birds included species regionally associated with arable agriculture and pastureland (Moreira, 1999; Delgado and Moreira, 2000). Steppe birds included a subset of the farmland species, corresponding to open grassland species of conservation concern that may be particularly sensitive to habitat fragmentation (Brotons et al., 2005; Moreira et al., 2005). A group of ground-nesting birds was also considered, because increased nest predation is often invoked to explain edge avoidance in open habitat birds (Vickery et al., 1992; Burger et al., 1994).

\subsection{Explanatory variables}

Distance to the nearest forest edge was the main variable used to investigate bird responses to edges. In addition, 16 variables reflecting forest plantation characteristics, edge contrast and landscape context (Table 1) were used to examine the influence of habitat variables on edge responses. Tree species and plantation age and area characterized forest plantations. Edge contrast (sensu Ries et al., 2004) was estimated from the height and density of trees at the boundary of forest plantations, assuming that taller and denser plantations reflect a higher contrast between edges and adjacent agricultural land. These variables were computed from digital photographs taken at known distances (usually 70-90 m), perpendicularly to the forest edge. Presence of trees in the agricultural matrix was taken to indicate softer forest-farmland transitions. Landscape context was estimated in 1-km radius circles from each sampling point located at the forest edge. This radius was set large enough to encompass different land uses despite the relative homogeneity of the landscape, while remaining within the range of scales to which farmland birds are responsive (e.g., Söderström and Pärt, 2000; Best et al., 2001; Moreira et al., 2005). The proportion of land occupied by open oak woodlands and by pine, oak and eucalyptus plantations was quantified in a Geographic Information System (GIS), from maps prepared using aerial photography and field surveys. Landscape fragmentation was estimated from the mean size, edge density and the area-weighted mean shape index (AWMSI) of open arable patches. AWMSI is a measure of shape complexity, which is the average perimeter-to-area ratio for a given class, weighted by the size of its patches (Rempel and Carr, 2003). The latter variable measures the extent to which patch shapes deviates from circularity, reflecting increases in edge-affected habitats with increasing patch complexity. Landscape metrics were computed using the Patch Analyst extension (version 3.1) of Arc View ${ }^{\circledR}$ GIS (Rempel and Carr, 2003).

\subsection{Statistical analysis}

Prior to statistical analysis, species richness and abundance data, and habitat variables showing skewed distributions were log-transformed to approach normality and to reduce the influence of extreme values. The angular transformation 
Table 1 - Description and summary statistics of variables used to examine the influence of habitat conditions on bird responses to forest edges in southern Portugal.

\begin{tabular}{|c|c|c|c|c|c|}
\hline Variable (unit) & Description & Transformation & Mean & S.D. & Range \\
\hline \multicolumn{6}{|l|}{ Forest plantation attributes } \\
\hline Eucalyptus plantations & $\begin{array}{l}\text { Binary variable coding plantations } \\
\text { dominated by eucalyptus }\end{array}$ & - & 0.2 & 0.4 & $0-1$ \\
\hline Pine plantations & $\begin{array}{l}\text { Binary variable coding plantations } \\
\text { dominated by umbrella pines }\end{array}$ & - & 0.3 & 0.5 & $0-1$ \\
\hline Oak plantations & $\begin{array}{l}\text { Binary variable coding plantations } \\
\text { dominated by cork or or holm oaks }\end{array}$ & - & 0.5 & 0.5 & $0-1$ \\
\hline Plantation age (years) & Age of the forest stand & - & 14.4 & 13.6 & $1-60$ \\
\hline Plantation area (ha) & Area of the forest plantation & Logarithmic & 45.6 & 34.1 & $0.7-123.3$ \\
\hline \multicolumn{6}{|l|}{ Edge contrast } \\
\hline Tree density (trees/m) & Density of trees at plantation edges & - & 0.3 & 0.2 & $0-0.8$ \\
\hline Tree height $(\mathrm{m})$ & Mean tree height at plantation edges & Logarithmic & 3.7 & 4.5 & $0-17.3$ \\
\hline Farmland trees & $\begin{array}{l}\text { Binary variable coding the presence of } \\
\text { isolate trees in adjacent }(<300 \mathrm{~m}) \text { farmland }\end{array}$ & - & 0.3 & 0.5 & $0-1$ \\
\hline \multicolumn{6}{|l|}{ Landscape context } \\
\hline Eucalyptus plantations cover (\%) & $\begin{array}{l}\text { Proportion of area within 1-km radius with } \\
\text { eucalyptus plantations }\end{array}$ & Angular & 3.0 & 5.5 & $0-23.6$ \\
\hline Pine plantations cover (\%) & $\begin{array}{l}\text { Proportion of area within } 1-\mathrm{km} \text { radius with } \\
\text { pine plantations }\end{array}$ & Angular & 7.0 & 10.2 & 0-39.4 \\
\hline Oak plantations cover (\%) & $\begin{array}{l}\text { Proportion of area within } 1-\mathrm{km} \text { radius with } \\
\text { oak plantations }\end{array}$ & Angular & 12.6 & 12.4 & 0-36.1 \\
\hline Total forest plantations cover (\%) & $\begin{array}{l}\text { Proportion of area within 1-km radius with } \\
\text { forest plantations }\end{array}$ & Angular & 22.5 & 11.8 & $0.4-51.9$ \\
\hline Total agro-forestry cover (\%) & $\begin{array}{l}\text { Proportion of area within 1-km radius with } \\
\text { open oak woodlands }\end{array}$ & Angular & 7.7 & 11.1 & $0-45.7$ \\
\hline Mean Patch Size (ha) & Mean size of forest patches & Logarithmic & 134.3 & 88.1 & $7.7-304.1$ \\
\hline Edge density $\left(\mathrm{km} / \mathrm{km}^{2}\right)$ & Density of forest edges & - & 4.0 & 1.1 & $1.1-7.8$ \\
\hline AWMSI & Area-weighted mean shape index & - & 2.2 & 0.6 & $1.3-4.1$ \\
\hline
\end{tabular}

(arcsine $\sqrt{p}$ ) was used likewise for proportional habitat data, overcoming problems associated with the unity sum constraint (Zar, 1996). A Principal Component Analysis (PCA) of habitat variables was used to investigate multicollinearity and to describe dominant gradients in forest, edge and landscape characteristics (Legendre and Legendre, 1998). A varimax normalized rotation was applied to the set of principal components with eigenvalues $>1$, to obtain simpler and more interpretable ecological gradients (Legendre and Legendre, 1998). PCA analyses were produced in STATISTICA 8.0 (Statsoft, 2008) under Multivariate Exploratory Techniques module with factor analyses function.

Edge responses were analysed with linear mixed-effects models (Pinheiro and Bates, 2000), thereby accounting for the potential lack of independence among bird counts within a transect at varying distances from a forest edge (e.g., Betts et al., 2006). In the present design individual transects were treated as random effects and all other explanatory variables as fixed effects. All mixed models were fitted in R 2.7.2 ( $R$ Development Core Team, 2008) software using the lme function of the nlme package (Pinheiro et al., 2007). The analysis started by modelling variation in species richness and abundances in relation to distance $(d)$ to edge. In each case, three different functions of distance were tested by specifying linear $\left(t_{d}=d\right)$, logarithmic $\left(t_{d}=\log _{10}[d+1]\right)$ and power $\left(t_{d}=d^{2}\right)$ transformations of the predictor variable. Recent approaches using more complex response curves (Ewers and Didham, $2006 b$ ) were not considered, because they are still inadequate to deal with covariates and mixed-effects designs (Robert M. Ewers, personal communication). The information-theoretic approach was then used as a model selection procedure (Burnham and Anderson, 2002), whereby the best fitting model was that with the lowest value of the Akaike's information criterion (AIC). Uncertainty in model selection was accounted for using Akaike weights $\left(w_{i}\right)$, which indicate the strength of evidence for a particular model being the best out of the set of candidate models (Burnham and Anderson, 2002). ANOVA tests comparing the best AIC models with the models fitted to the intercept only (null models) were then used to strengthen the support to inferences drawn from the information-theoretic approach (Stephens et al., 2005; but see Lukacs et al., 2007). The penetration of edge effects beyond $300 \mathrm{~m}$ was assessed using one-way ANOVAs, comparing bird counts at $300 \mathrm{~m}$ and at $300-5000 \mathrm{~m}$ from the nearest wooded edge.

The second set of analyses examined whether bird response to edges were affected by environmental gradients reflected in components extracted from the habitat PCA. These analyses excluded species and functional groups lacking evidence for edge responses, assuming that environmental modifiers of an edge response could only be clearly assessed when there was evidence for an overall edge effect. For each species or functional group, different hypothesis concerning the effects of each principal component $\left(P C_{i}\right)$ on the shape of the responses curves were assessed by fitting three alternative $a$ priori models $\left(g_{\mathrm{i}}\right)$ : 


\begin{tabular}{|c|c|}
\hline$g_{1}=\beta_{0}+\beta_{1} \cdot t_{d}+\beta_{2} \cdot P C i$ & $\begin{array}{l}\text { (effects on the intercept, } \\
\text { reflecting variation in diversity } \\
\text { or abundance at the edge) }\end{array}$ \\
\hline$g_{2}=\beta_{0}+\beta_{1} \cdot t_{d}+\beta_{2} \cdot t_{d} \cdot P C_{i}$ & $\begin{array}{l}\text { (effects on slope, reflecting } \\
\text { variation in the rate of change } \\
\text { in diversity or abundance with } \\
\text { distance) }\end{array}$ \\
\hline$g_{3}=\beta_{0}+\beta_{1} \cdot t_{d}+\beta_{2} \cdot P C_{i}+\beta_{3} \cdot t_{d} \cdot P C_{i}$ & $\begin{array}{l}\text { (effects on both intercept and } \\
\text { slope) }\end{array}$ \\
\hline
\end{tabular}

where $t_{d}$ is the transformation of distance yielding the best AIC model in previous analysis. The strength of evidence for each model was then estimated using Akaike weights $\left(w_{i}\right)$, and the model with the highest $w_{i}$ was selected for each $P C_{i}$. This procedure follows the recommendation to retain only the model with the lowest AIC from a set of nested candidate models (Richards, 2008). Comparison among the reduced subset of models, including the null model and one model for each $P C_{i}$, was then based on conditional Akaike weights, estimated as the original $w_{i}$ normalized to sum to 1. The information-theoretic approach was complemented with conventional statistical testing, using ANOVA to compare the best AIC models to the models fitted only to the distance to edge variable (null models).

\section{Results}

\subsection{Overall habitat patterns}

Sampled edges represented a wide range of variability in plantation, edge and landscape characteristics (Table 1). The PCA extracted five axes with eigenvalues $>1$, together accounting for $81 \%$ of variance in the original data (Table 2). The varimax rotation revealed a major gradient (PC1) largely reflecting dominant forest types, contrasting landscapes with plantations dominated by either eucalyptus or oaks stands.
Eucalyptus plantations were generally older and taller, whereas oak stands tended to be larger and located in landscapes with greater overall cover by forest plantations. The type of forest plantation was also reflected in a secondary gradient contrasting oak and pine stands (PC2), the latter showing higher tree density. The third and fourth rotated PCA axes were largely related to landscape fragmentation. PC3 represented primarily the concurrent increase of edge density and shape complexity of open arable patches, whereas PC4 largely reflected variation in the mean size of open arable patches, which was inversely related with eucalyptus and overall plantation cover. PC5 represented the presence of farmland trees, which were more prevalent in landscapes with greater cover by agro-forestry systems.

\subsection{Bird assemblage composition}

Altogether, 47 bird species were recorded around (<300 m) forest plantations (Appendix), with an average $6.5 \pm 2.5$ species and $15.8 \pm 14.4$ birds per transect. About half (51\%) the species were typical of arable farmland, of which $71 \%$ were groundnesters and $46 \%$ were steppe birds. In terms of abundance, the assemblage was also dominated by arable farmland species ( $59 \%$ of birds counted), most of which were ground-nesters $(87 \%)$ and about half of which were steppe birds (49\%). Only nine species were widespread ( $>25 \%$ of transects) and abundant ( $>1$ bird/10 ha), accounting for $55.7 \%$ of the birds counted. This group was dominated by breeding species typical of arable farmland, including little bustards (Tetrax tetrax), crested/Thekla larks (Galerida spp.), calandra larks (Melanocorypha calandra), short-toed larks (Calandrella brachydactyla), tawny pipits (Anthus campestris), stonechats (Saxicola torquatus), and corn buntings (Emberiza calandra), though there were also two species requiring woody vegetation during the breeding season (goldfinch Carduelis carduelis) and linnets (Carduelis cannabina).

Table 2 - Loadings of habitat variables on the first five axes extracted by a PCA, after a varimax normalized rotation, and the proportion of variance accounted for by each axis. For clarity, only loadings $>10.40 \mid$ were listed.

\begin{tabular}{|c|c|c|c|c|c|}
\hline Habitat variables & PC1 & PC2 & PC3 & PC4 & PC5 \\
\hline Eucalyptus plantations & 0.93 & & & & \\
\hline Pine plantations & & -0.85 & & & \\
\hline Oak plantations & -0.68 & 0.65 & & & \\
\hline Plantation age & 0.79 & & & & \\
\hline Plantation area & -0.77 & & & & \\
\hline Tree density & & -0.68 & & & \\
\hline Tree height & 0.93 & & & & \\
\hline Farmland trees & & & & & 0.85 \\
\hline Eucalyptus plantations cover & 0.56 & & & 0.57 & \\
\hline Pine plantations cover & & -0.86 & & & \\
\hline Oak plantations cover & -0.69 & 0.53 & & & \\
\hline Total forest plantations cover & -0.73 & & & 0.57 & \\
\hline Total agro-forestry cover & & & & & 0.55 \\
\hline Mean patch size & & & & -0.83 & \\
\hline Edge density & & & 0.93 & & \\
\hline AWMSI & & & 0.93 & & \\
\hline Percentage of total variance & 30.6 & 18.5 & 11.9 & 10.7 & 9.4 \\
\hline
\end{tabular}


Table 3 - Akaike weights $\left(w_{\mathrm{i}}\right)$ for four alternative models describing variation in bird species richness and abundance with distance from forest edges.

\begin{tabular}{|c|c|c|c|c|}
\hline & Null & Linear & Power & Logarithmic \\
\hline \multicolumn{5}{|l|}{ Richness } \\
\hline Overall & $<0.01$ & $<0.01$ & $<0.01$ & $>0.99^{* \cdots}$ \\
\hline Farmland & 0.10 & 0.04 & 0.05 & $0.81^{*}$ \\
\hline Steppe & $<0.01$ & $0.75^{* * *}$ & 0.25 & $<0.01$ \\
\hline Ground-nesting & 0.20 & 0.07 & 0.11 & $0.62^{*}$ \\
\hline Woodland & $<0.01$ & $<0.01$ & $<0.01$ & $>0.99^{* * *}$ \\
\hline \multicolumn{5}{|l|}{ Abundance } \\
\hline Overall & $<0.01$ & $<0.01$ & $<0.01$ & $0.99^{* * * *}$ \\
\hline Farmland & 0.22 & 0.10 & $0.39^{\S}$ & 0.29 \\
\hline Steppe & $<0.01$ & $0.55^{* * *}$ & 0.45 & $<0.01$ \\
\hline Ground-nesting & 0.22 & 0.13 & $0.47^{\S}$ & 0.17 \\
\hline Woodland & $<0.01$ & $<0.01$ & $<0.01$ & $>0.99^{*+*}$ \\
\hline \multicolumn{5}{|l|}{ Species abundances } \\
\hline Little bustard & 0.38 & 0.21 & 0.27 & 0.15 \\
\hline Galerida larks & $<0.01$ & 0.19 & 0.04 & $0.77^{* * *}$ \\
\hline Short-toed lark & $<0.01$ & 0.19 & $0.81^{* * *}$ & $<0.01$ \\
\hline Calandra lark & $<0.01$ & $0.86^{* * *}$ & 0.14 & $<0.01$ \\
\hline Tawny pipit & 0.29 & 0.27 & 0.20 & 0.24 \\
\hline Stonechat & $<0.01$ & 0.02 & $<0.01$ & $0.97^{* * *}$ \\
\hline Linnet & 0.19 & $0.29^{\S}$ & 0.24 & 0.28 \\
\hline Goldfinch & 0.02 & 0.04 & 0.01 & $0.93^{* *}$ \\
\hline Corn bunting & $<0.01$ & $<0.01$ & $<0.01$ & $>0.99$ \\
\hline $\begin{array}{l}\text { Linear, square-p } \\
\text { with the greates } \\
\text { models) are pro } \\
{ }^{*} P<0.05 . \\
{ }^{* *} P<0.01 . \\
{ }^{* * *} P<0.001 . \\
\text { \& } P<0.10 .\end{array}$ & $\begin{array}{l}c \text { trans } \\
\text { hted in }\end{array}$ & $\begin{array}{l}\text { e were us } \\
\text { al signific }\end{array}$ & $\begin{array}{l}\text { ive edge } \\
\text { s with mo }\end{array}$ & $\begin{array}{l}\text { ghts of models } \\
\text { intercept (null }\end{array}$ \\
\hline
\end{tabular}

\subsection{Bird responses to edges}

Akaike weights provided much stronger support to models including distance to edge as a predictor of bird species richness $\left(1.0>\Sigma w_{i}>0.80\right)$ than to the corresponding null models of no edge effects (Table 3 ). There was considerable evidence $\left(w_{\mathrm{i}}>0.95\right)$ for exponential decays in overall and woodland species richness with increasing distance from plantation edges, with comparable declines, albeit not as strong, for the richness of farmland and ground-nesting species (Fig. 1). Only the richness of steppe birds increased along with distance to edge (Fig. 1). There was strong evidence for the total abundance of birds and that of woodland birds to decline exponentially away from edges, whereas linear increases were recorded in steppe bird abundance (Fig. 1). The best AIC models for farmland and ground-nesting bird suggested slight increases in abundance at greater distance from edges, but these models were only marginally significant $(P<0.10)$ and not clearly superior to the alternative models (Table 3 ).

Seven of the nine most abundant and widespread species were affected by plantation edges, whereas little support for edge effects was found for little bustards and tawny pipits (Table 3). The abundance of five species declined with increasing distance to edges, with strong support for exponential decays $\left(1.00>w_{i}>0.77\right)$ in the case of Galerida larks, stonechats, goldfinches and corn buntings, and a weak support for linear declines for the linnet (Table 3; Fig. 1). The best AIC models for short-toed lark and calandra lark reflected strongly negative edge effects, with abundances steadily increasing away from edges.

Penetration of edge effects beyond the maximum length of the sampling transect was only apparent for woodland birds, with significantly $\left(F_{1,78}=11.068, P<0.001\right)$ more woodland species per point count at $300 \mathrm{~m}(0.29 \pm 0.46)$ than at $>300 \mathrm{~m}$ (no species recorded). The tendency for more steppe bird species per point count at $>300 \mathrm{~m}(1.46 \pm 0.84)$ than at $300 \mathrm{~m}$ $(1.13 \pm 0.79)$ was close to statistical significance $\left(F_{1,78}=3.024\right.$, $P<0.086)$.

\subsection{Interactions affecting edge responses}

There was strong evidence for the composition of forest plantations and the fragmentation of open arable habitats to affect edge responses of bird functional groups (Table 4, Figs. 2 and 3). The environmental gradient represented in the first PC axis (PC1) affected the richness (Fig. 2) and abundance (Fig. 3) of the overall assemblage and that of woodland birds, with more species and more birds near tall and old eucalyptus plantations, than near recent oak plantations. Total species richness remained consistently higher around eucalyptus than oak plantations, irrespective of distance to edges. Conversely, the decline in total bird abundance and in the richness and abundance of woodland birds was sharper away from eucalyptus edges, tending to converge to the oak edge response curve. The number of steppe bird species was higher near oak than near eucalyptus edges (PC1), but con- 

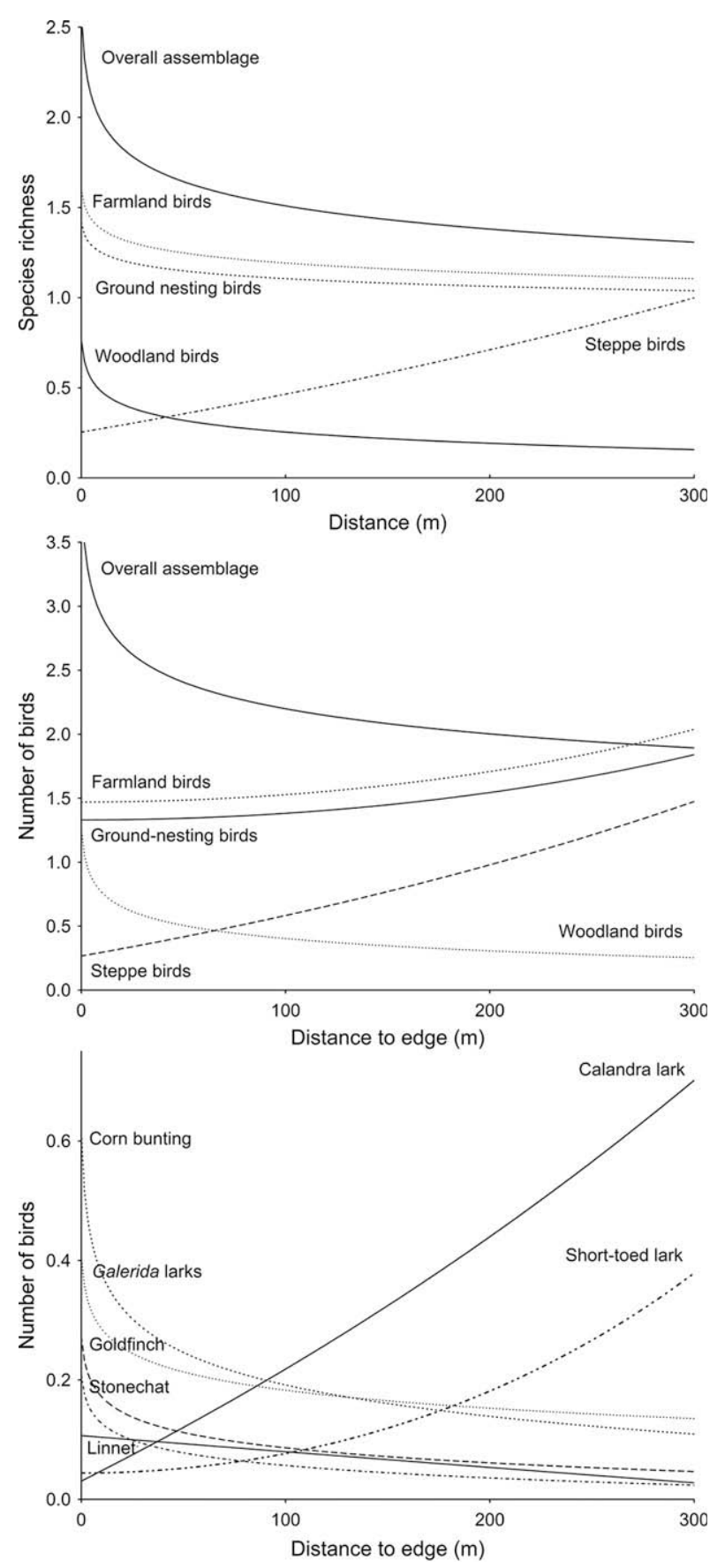

Fig. 1 - Edge response curves describing variation in species richness and abundance of bird functional groups, and in the abundance of the most common species, as a function of distance to forest plantation edges in southern Portugal.

verged to similar, much higher values at about $300 \mathrm{~m}$ from the edge (Fig. 2). The abundance of farmland and ground-nesting birds increased away from eucalyptus edges, whereas there was almost no response to oak edges (Fig. 3). The fragmentation gradient reflected in PC4 affected in a similar way the overall species richness and that of farmland and groundnesting (graph not shown) birds, with similar number of species near edges irrespective of landscape fragmentation, but sharper declines away from edges in landscapes with smaller arable patches (Figs. 2 and 3). The richness (Fig. 2) and abundance (Fig. 3) of steppe birds was low near edges irrespective of landscape fragmentation, increasing to much higher values in landscapes with larger arable patches. The abundance of ground-nesting birds was higher in less fragmented landscapes irrespective of distance from edges (Fig. 3).

Edge contrast and landscape fragmentation also affected both positive and negative edge responses by individual species (Table 4, Fig. 4). The edge type reflected in PC1 influenced edge responses of Galerida larks, linnets, goldfinches, and corn buntings. There were more linnets, goldfinches and corn buntings near mature eucalyptus plantations than near recent oak plantations, but their numbers declined with increasing distance from edges. The slope of the goldfinch edge response curve was also affected by PC1, reflecting a convergence to low abundances at about $300 \mathrm{~m}$ from all edges, albeit still higher around eucalyptus plantations. Galerida larks showed similar abundance near all edges, but there was a tendency for weaker edge responses to eucalyptus plantations. However, the AIC support for this model was weak and it was not statistically significant, thereby requiring caution in its interpretation. The type of edge reflected in PC2 influenced edge responses of linnets, stonechats and short-toed larks. Linnets were more abundant near pine than oak edges, but their abundances at $300 \mathrm{~m}$ from edges were very low irrespective of edge type. Stonechats showed the opposite pattern, with higher abundances near oak edges. Short-toed larks were scarce close to all edge types, but they increased in abundance away from edges more sharply around pine plantations. Edge density (PC3) influenced edge responses of corn buntings and shorttoed larks. Corn bunting abundances were higher near edges in landscapes with smaller edge density, but their numbers tended to converge to small values away from edges irrespective of landscape fragmentation. More short-toed larks were found near edges in more fragmented landscapes, but the abundance of this species increased away from edges irrespective of landscape fragmentation. The mean size of arable patches (PC4) influenced edge responses of stonechats and calandra larks. Stonechat abundances varied little with distance to edge in landscapes with smaller arable patches, whereas they showed high abundances near edges and sharp declines away from edges in landscapes with large arable patches. Calandra larks were largely absent close edges irrespective of arable patch size, but their abundance away from edges increased faster in landscapes with larger arable patches.

\section{Discussion}

\subsection{Edge effects}

Planted forests significantly influenced the bird assemblages of adjacent open land, underlining the value of investigating edge effects to understand the impacts of afforestation on biodiversity. Contrary to expectations developed from the observation that many open habitat birds avoid wooded boundaries (Coppedge et al., 2004; Fletcher, 2005), however, it was found that most birds in southern Portugal showed either positive or neutral edge responses. Positive responses were apparent for typical farmland birds such as Galerida larks, stonechats, and corn buntings, which are frequently 

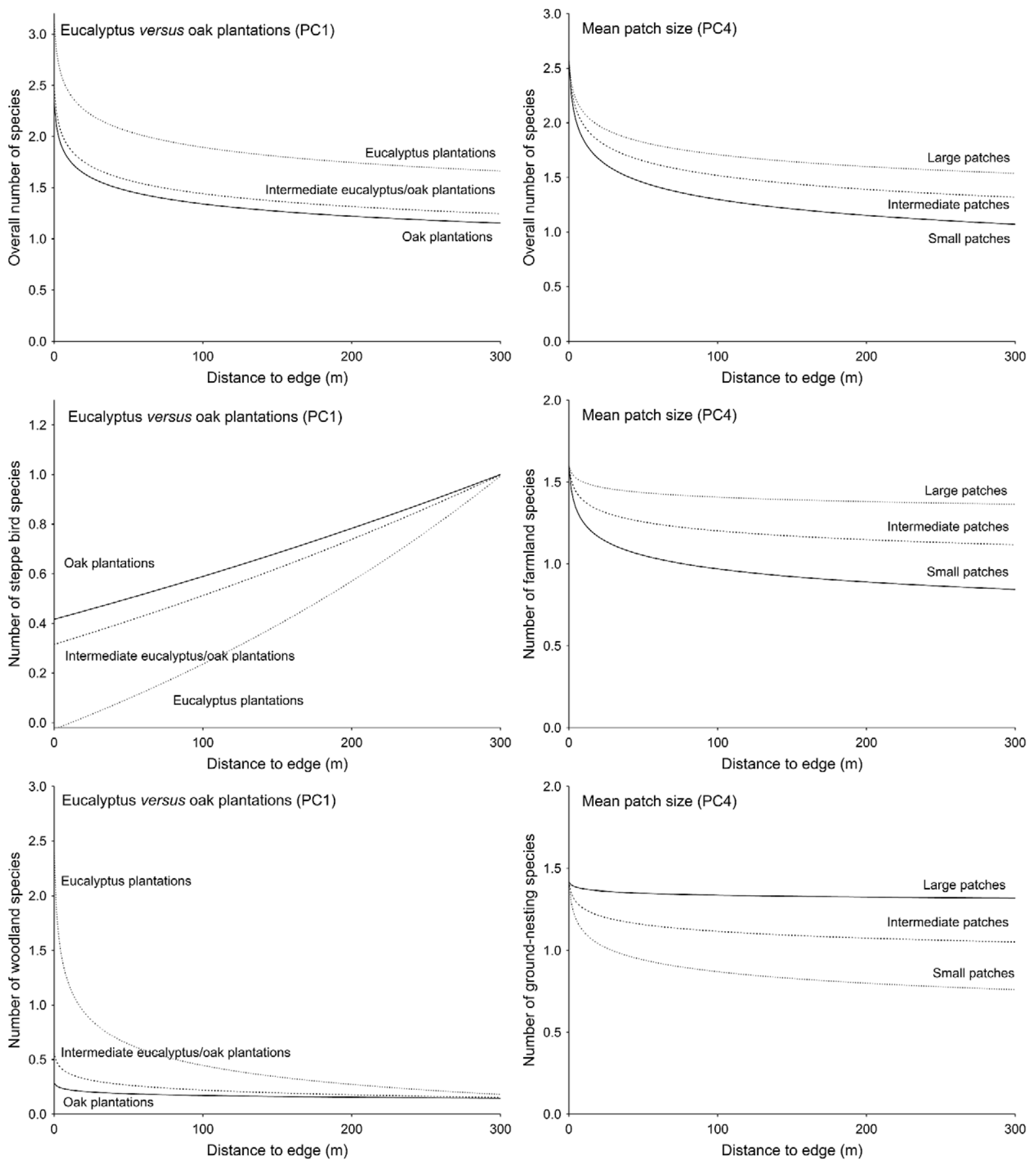

Fig. 2 - Variation in edge response curves for the species richness of bird functional groups as a function of environmental gradients $\left(P C_{i}\right)$ extracted from a Principal Components Analysis of habitat variables. Curves represented in each panel reflect model fitted edge responses for the 1st $(-), 5$ th $(--)$ and 9 th $(\cdots)$ deciles of the distribution of sample scores in a PC axis.

associated with open habitats (Moreira, 1999; Delgado and Moreira, 2000). Only the steppe birds, a group including the open grassland specialists, showed marked negative responses to wooded edges, in terms of both species richness and abundances. The negative responses were very strong in the case of the calandra lark and the short-toed lark, but no evidence for edge avoidance was found for little bustards and tawny pipits. Patterns for other open habitat species of high conservation concern, such as great bustards (Otis tarda), stone curlews (Burhinus oedicnemus) or black-bellied sand- grouse (Pterocles orientalis) could not be obtained in this study, because they were scarcely observed at point counts. Furthermore, these species are wide ranging and so probably operate at large spatial scales, requiring a different sampling design to assess their responses to wooded edges.

The increase in woodland birds near wooded edges probably occurs due to spill over from forest plantations, as these species are largely absent from open farmland landscapes (Moreira, 1999; Delgado and Moreira, 2000) and they benefit from habitat conditions created through afforestation (Díaz 
Table 4 - Akaike weights $\left(w_{i}\right)$ for alternative models describing factors affecting bird response curves to forest edges in southern Portugal.

\begin{tabular}{|c|c|c|c|c|c|c|c|c|c|c|c|c|c|c|c|c|}
\hline & \multirow{2}{*}{$\begin{array}{l}\text { Null } \\
\text { go }\end{array}$} & \multicolumn{3}{|c|}{ PC1 } & \multicolumn{3}{|c|}{ PC2 } & \multicolumn{3}{|c|}{ PC3 } & \multicolumn{3}{|c|}{ PC4 } & \multicolumn{3}{|c|}{ PC5 } \\
\hline & & $g_{1}$ & $g_{2}$ & $g_{3}$ & $g_{1}$ & $g_{2}$ & $g_{3}$ & $g_{1}$ & $\mathrm{~g}_{2}$ & $g_{3}$ & $g_{1}$ & $g_{2}$ & $g_{3}$ & $g_{1}$ & $g_{2}$ & $g_{3}$ \\
\hline \multicolumn{17}{|l|}{ Richness } \\
\hline \multirow[t]{2}{*}{ Overall } & (a) 0.06 & 0.29 & 0.06 & 0.17 & 0.02 & 0.02 & 0.01 & 0.05 & 0.07 & 0.03 & 0.04 & 0.09 & 0.04 & 0.02 & 0.02 & 0.01 \\
\hline & (b) 0.10 & $0.52^{*}$ & & & & 0.04 & & & 0.12 & & & $0.17^{\S}$ & & & 0 & \\
\hline \multirow[t]{2}{*}{ Farmland } & (a) 0.08 & 0.03 & 0.07 & 0.10 & 0.04 & 0.03 & 0.02 & 0.06 & 0.05 & 0.02 & 0.10 & 0.25 & 0.10 & 0.03 & 0.03 & 0.01 \\
\hline & (b) 0.14 & & & 0.17 & 0.07 & & & 0.11 & & & & $0.46^{*}$ & & 0.05 & & \\
\hline \multirow[t]{2}{*}{ Steppe } & (a) 0.02 & 0.08 & 0.01 & 0.21 & 0.01 & 0.01 & 0.01 & 0.01 & 0.01 & 0.00 & 0.05 & 0.42 & 0.16 & 0.01 & 0.01 & 0.01 \\
\hline & (b) 0.03 & & & $0.31^{*}$ & 0.01 & & & & 0.01 & & & $0.62^{*}$ & & 0.02 & & \\
\hline \multirow[t]{2}{*}{ Ground-nesting } & (a) 0.06 & 0.02 & 0.04 & 0.06 & 0.03 & 0.02 & 0.01 & 0.04 & 0.03 & 0.02 & 0.15 & 0.34 & 0.13 & 0.02 & 0.02 & 0.01 \\
\hline & (b) 0.11 & & & 0.10 & 0.05 & & & 0.08 & & & & $0.62^{*}$ & & 0.04 & & \\
\hline \multirow[t]{2}{*}{ Woodland } & (a) 0.00 & 0.00 & 0.00 & 1.00 & 0.00 & 0.00 & 0.00 & 0.00 & 0.00 & 0.00 & 0.00 & 0.00 & 0.00 & 0.00 & 0.00 & 0.00 \\
\hline & (b) 0.00 & & & $1.00^{* * *}$ & 0.00 & & & & 0.00 & & 0.00 & & & 0.00 & & \\
\hline \multicolumn{17}{|l|}{ Abundance } \\
\hline \multirow{2}{*}{ Overall } & (a) 0.00 & 0.24 & 0.00 & 0.75 & 0.00 & 0.00 & 0.00 & 0.00 & 0.00 & 0.00 & 0.00 & 0.00 & 0.00 & 0.00 & 0.00 & 0.00 \\
\hline & (b) 0.00 & & & $0.99^{* * *}$ & 0.00 & & & & 0.00 & & & & 0.01 & 0.00 & & \\
\hline \multirow[t]{2}{*}{ Farmland } & (a) 0.01 & 0.00 & 0.36 & 0.56 & 0.00 & 0.00 & 0.00 & 0.01 & 0.01 & 0.00 & 0.02 & 0.02 & 0.01 & 0.00 & 0.00 & 0.00 \\
\hline & (b) 0.01 & & & $0.93^{* * *}$ & 0.00 & & & & 0.01 & & 0.03 & & & 0.00 & & \\
\hline \multirow[t]{2}{*}{ Steppe } & (a) 0.00 & 0.01 & 0.00 & 0.02 & 0.00 & 0.00 & 0.00 & 0.00 & 0.00 & 0.00 & 0.03 & 0.66 & 0.26 & 0.00 & 0.00 & 0.00 \\
\hline & (b) 0.01 & & & 0.03 & & 0.00 & & & 0.00 & & & $0.95^{* * *}$ & & 0 & & \\
\hline \multirow[t]{2}{*}{ Ground-nesting } & (a) 0.05 & 0.02 & 0.17 & 0.13 & 0.02 & 0.03 & 0.02 & 0.04 & 0.05 & 0.02 & 0.24 & 0.07 & 0.09 & 0.02 & 0.02 & 0.01 \\
\hline & (b) 0.10 & & $0.30^{*}$ & & & 0.05 & & & 0.09 & & $0.43^{*}$ & & & 0.04 & & \\
\hline \multirow[t]{2}{*}{ Woodland } & (a) 0.00 & 0.00 & 0.00 & 1.00 & 0.00 & 0.00 & 0.00 & 0.00 & 0.00 & 0.00 & 0.00 & 0.00 & 0.00 & 0.00 & 0.00 & 0.00 \\
\hline & (b) 0.00 & & & $1.00^{* * *}$ & 0.00 & & & & 0.00 & & & & 0.00 & 0.00 & & \\
\hline \multicolumn{17}{|l|}{ Species abundances } \\
\hline \multirow[t]{2}{*}{ Galerida larks } & (a) 0.11 & 0.08 & 0.19 & 0.08 & 0.10 & 0.07 & 0.04 & 0.04 & 0.05 & 0.03 & 0.05 & 0.04 & 0.03 & 0.04 & 0.04 & 0.02 \\
\hline & (b) 0.21 & & $0.35^{\S}$ & & 0.19 & & & & 0.09 & & 0.08 & & & & 0.08 & \\
\hline Short-toed lark & (a) 0.06 & 0.02 & 0.03 & 0.01 & 0.03 & 0.09 & 0.04 & 0.32 & 0.07 & 0.12 & 0.03 & 0.06 & 0.03 & 0.04 & 0.03 & 0.02 \\
\hline & (b) 0.10 & & 0.04 & & & $0.15^{\S}$ & & $0.53^{*}$ & & & & 0.11 & & 0.1 & & \\
\hline Calandra lark & (a) 0.00 & 0.00 & 0.00 & 0.00 & 0.00 & 0.00 & 0.00 & 0.00 & 0.00 & 0.00 & 0.00 & 0.72 & 0.28 & 0.00 & 0.00 & 0.00 \\
\hline & (b) 0.00 & 0.00 & & & & 0.00 & & & 0.00 & & & $1.00^{* * *}$ & & & 0 & \\
\hline Stonechat & (a) 0.04 & 0.02 & 0.02 & 0.01 & 0.15 & 0.02 & 0.37 & 0.01 & 0.01 & 0.02 & 0.03 & 0.01 & 0.25 & 0.01 & 0.01 & 0.01 \\
\hline & (b) 0.05 & 0.03 & & & & & $0.52^{*}$ & & & 0.02 & & & $0.36^{*}$ & & 0 & \\
\hline Linnet & (a) 0.04 & 0.22 & 0.03 & 0.13 & 0.20 & 0.02 & 0.26 & 0.01 & 0.01 & 0.01 & 0.01 & 0.01 & 0.01 & 0.02 & 0.01 & 0.01 \\
\hline & (b) 0.06 & $0.39^{*}$ & & & & & $0.47^{*}$ & & 0.03 & & 0.02 & & & 0.03 & & \\
\hline Goldfinch & (a) 0.00 & 0.42 & 0.01 & 0.55 & 0.00 & 0.00 & 0.00 & 0.00 & 0.00 & 0.00 & 0.01 & 0.00 & 0.01 & 0.00 & 0.00 & 0.00 \\
\hline & (b) 0.00 & $0.98^{* * *}$ & & & & 0.00 & & 0.00 & & & 0.02 & & & 0.00 & & \\
\hline Corn bunting & (a) 0.02 & 0.29 & 0.15 & 0.12 & 0.01 & 0.01 & 0.01 & 0.11 & 0.01 & 0.22 & 0.01 & 0.02 & 0.01 & 0.01 & 0.01 & 0.00 \\
\hline & (b) 0.03 & $0.51^{* *}$ & & & 0.02 & & & & & $0.39^{*}$ & & 0.03 & & 0.02 & & \\
\hline $\begin{array}{l}\text { Comparisons ir } \\
\text { (Table } 2): g_{0}=\mathrm{m} \\
\text { The table inclu } \\
\text { the null model } \\
\text { statistical signi } \\
{ }^{*} P<0.05 \text {. } \\
{ }^{* *} P<0.01 . \\
{ }^{* * *} P<0.001 . \\
\S P<0.10 .\end{array}$ & $\begin{array}{l}\text { luded th } \\
\text { del fit to } \\
\text { es Akaike } \\
\text { d the be } \\
\text { cances o }\end{array}$ & compa & $\begin{array}{l}\text { oased } \\
\text { lel for } \\
\text { ons w }\end{array}$ & the $\mathrm{n}$ & mod & 1 are $p$ & $\begin{array}{l}\text { eights } \\
\text { vided. }\end{array}$ & for & s with & he gr & est su & ort are & ighlig & ed in & $\begin{array}{l}\text { Is inc } \\
\text { old ty }\end{array}$ & $\begin{array}{l}\text { ables } \\
\text { lope. } \\
\text { ding } \\
\text { e and }\end{array}$ \\
\hline
\end{tabular}

et al., 1998; López and Moro, 1997; Santos et al., 2006). Most woodland birds occurred at $<200 \mathrm{~m}$ from edges, suggesting that they may be unable to use agricultural fields unless there is a dense network of wooded habitats. This finding is consistent with the results of gap crossing experiments which show an increased reluctance for woodland birds to venture into the open as the gaps between woodland fragments increase (Creegan and Osborne, 2005). It is much less clear why farmland and ground-nesting bird species richness and the abundance of many typical farmland species also tended to decline away from edges. One possible reason may be the difference in the characteristics of edge and interior grassland habitats, as forest plantations were fenced off from cattle whereas nearby fields were regularly grazed (personal observation). Because of this, a strip of relatively tall grassland, sometimes with small shrubs, often developed near forest plantations, probably providing better breeding conditions for many farmland birds than adjacent short swards (e.g., Yanes et al., 1996). This idea was supported by an experiment of predation on quail (Coturnix coturnix) eggs placed in artificial nests, which showed lower predation rates in tall swards near forest plantations (Reino et al., unpublished data). Taken together, these results agree with the observation that the richest bird assemblages in farmland landscapes are found 

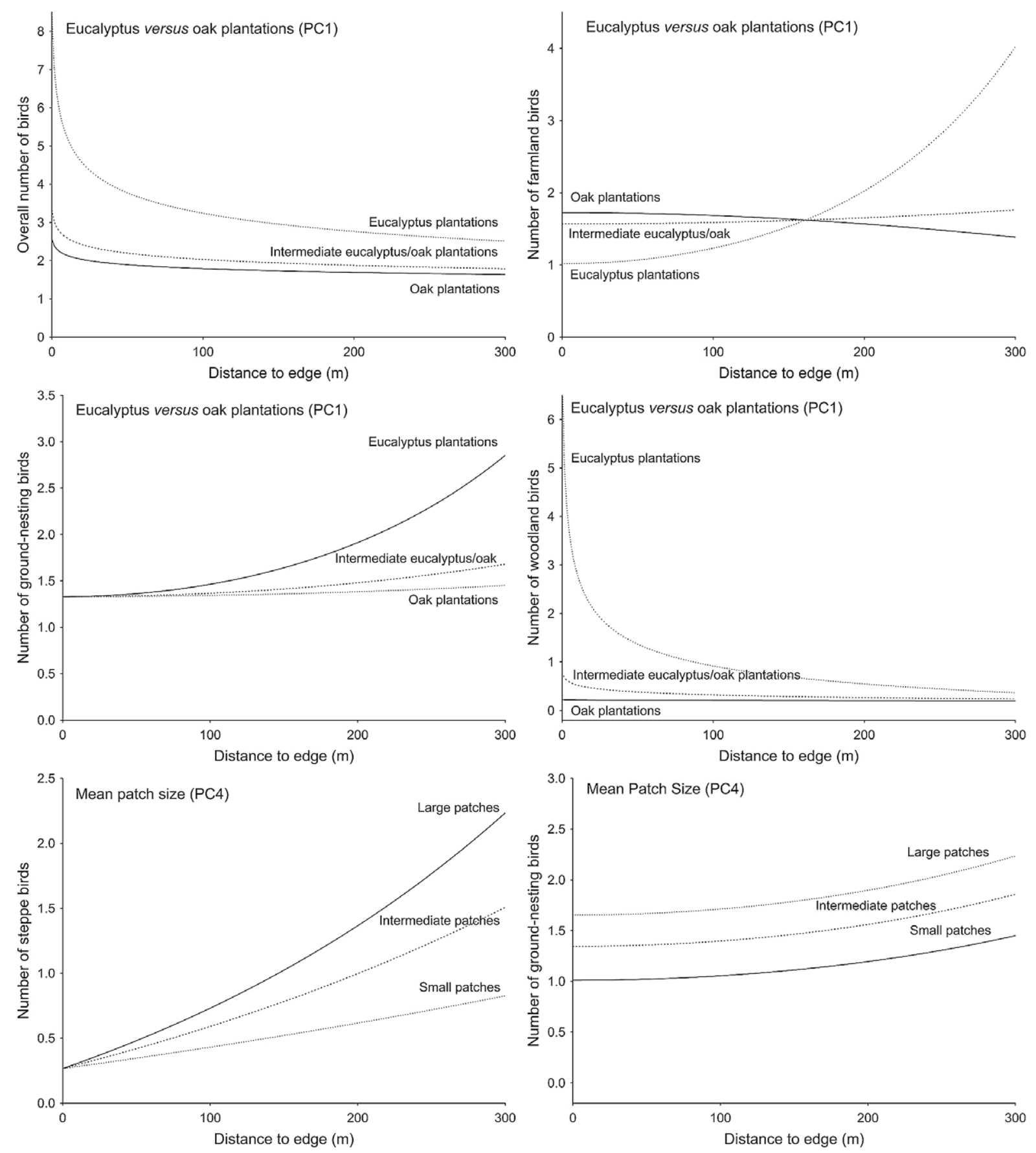

Fig. 3 - Variation in edge response curves for the abundance of bird functional groups as a function of environmental gradients $\left(P C_{i}\right)$ extracted from a principal components analysis of habitat variables. Curves represented in each panel reflect model fitted edge responses for the 1st $(-)$, 5th $(---)$ and 9 th $(\cdots)$ ) deciles of the distribution of sample scores in a PC axis.

where agricultural habitats are interspersed with wooded habitats such as woodlots and hedgerows (Freemark and Kirk, 2001; Moreira et al., 2005). The weak negative response to edges of farmland and ground-nesting bird abundances was likely a consequence of pooling species with contrasting edge responses. Although these groups included species showing marked positive edge responses, such as corn buntings and Galerida larks, the overall negative edge effect was probably driven by the influence of abundant steppe birds such as the calandra lark and the short-toed lark.
The only species showing marked negative responses to wooded edges were the true open habitat specialists, particularly the calandra lark and the short-toed lark. The abundance of both species steadily increased away from forest plantations, only reaching densities similar to that of core open habitats at about $300 \mathrm{~m}$ from edges. In contrast, two other open habitat species, the little bustard and the tawny pipit showed neutral responses to wooded edges. These patterns are difficult to interpret, as edge avoidance in grassland species may result from a combination of a variety of factors, 

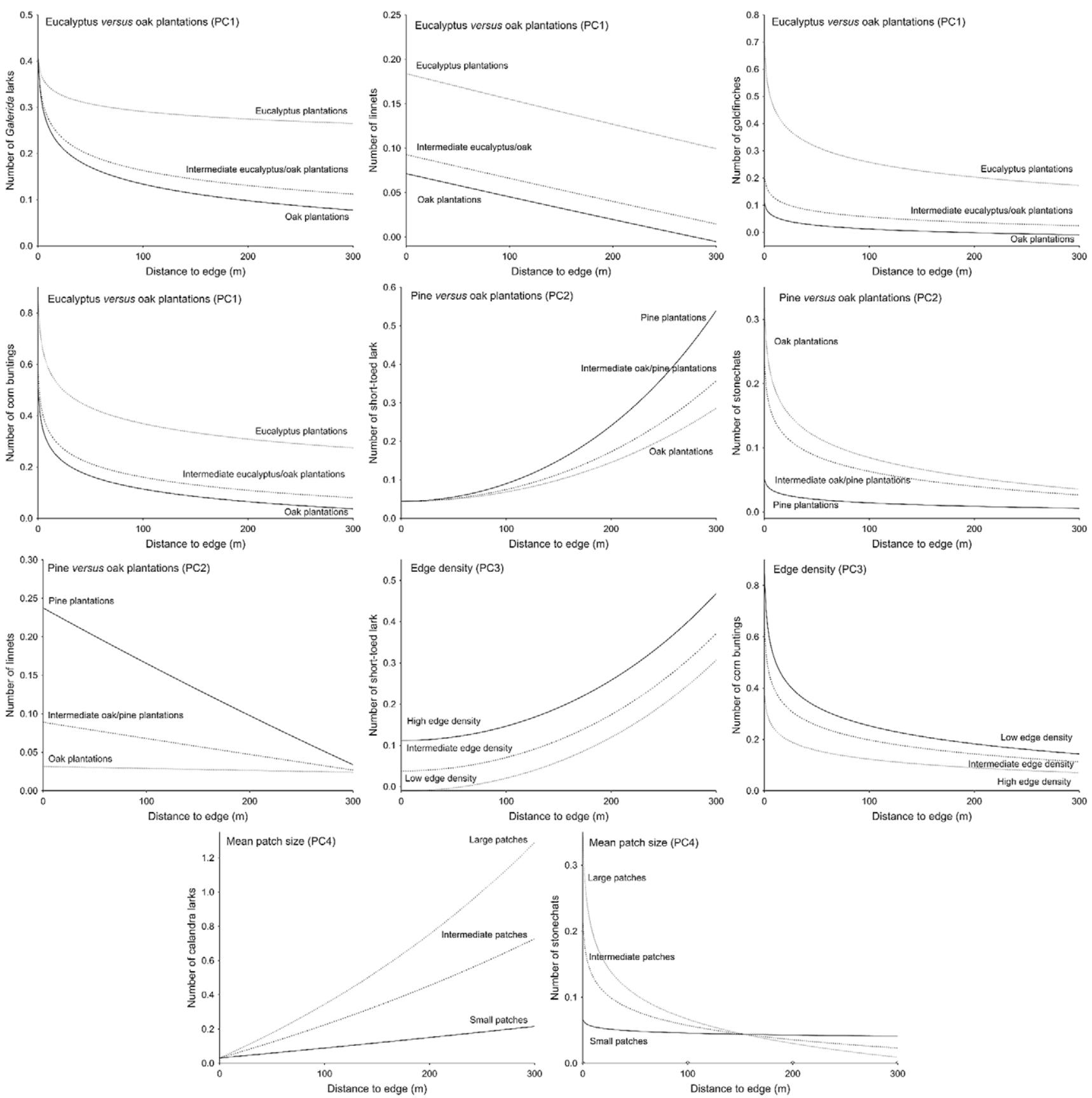

Fig. 4 - Variation in edge response curves for the most common bird species as a function of environmental gradients $\left(\mathrm{PC}_{\mathrm{i}}\right)$ extracted from a principal components analysis of habitat variables. Curves represented in each panel reflect model fitted edge responses for the 1st ( - , 5th $(--)$ and 9th $(\cdots \cdot)$ deciles of the distribution of sample scores in a PC axis.

from a learned response of poor reproductive success near edges to a mere innate requirement for open habitat (Bollinger and Gavin, 2004). Increased nest predation risk is often invoked to explain the avoidance of edges by grassland birds (Vickery et al., 1992; Burger et al., 1994), but this was unlikely to be very relevant here. This was supported by the observation that a range of ground-nesting farmland species analysed in this study showed positive or neutral response to wooded edges and by the lack of increased predation on artificial nests near edges recorded in a parallel study (Reino et al., unpublished data). It is possible that the avoidance of edges may have a behavioural basis with no adaptive value at present, resulting from the evolution of some grassland birds in expansive prairies and steppes with no wooded structures, which resulted in a strong aversion to less familiar features (Renfrew et al., 2005).

\subsection{Interactions affecting edge responses}

This study also supported the view that edge contrast affects bird responses to edges (Ries et al., 2004), with stronger effects recorded for eucalyptus (hard edges) than oak plantations 
(soft edges). In the study area, most eucalyptus plantations are tall and old, presumably providing more colonization opportunities for woodland birds than oak plantations, which tended to be young and short. The spill over of woodland birds into adjacent agricultural fields was thus stronger around eucalyptus than oak plantations, explaining the observed increase in overall species richness and abundance near eucalyptus edges. This pattern was illustrated by the goldfinch and the linnet, two species with woody requirements during the breeding season, which were relatively abundant in agricultural fields surrounding eucalyptus plantations and almost absent near young plantations. It is much less clear why the positive responses by farmland species such as the Galerida larks and the corn bunting were also stronger for eucalyptus than for oak plantation edges. It is possible that this was related to the older age of eucalyptus edges, as edge quality may change with time and there may be time lags in species responses (Ries et al., 2004). It is also possible that the edges of oak plantations are perceived by these birds as less stable, due to more frequent silvicultural operations in recent stands. The edge avoidance response of steppe birds was also stronger for eucalyptus than oak plantation edges. This could possibly be related to the visual obstruction effect of tall eucalyptus edges, which is likely to elicit a much stronger aversion by open grassland birds than the short oak plantations. The overall response of farmland birds and ground-nesting birds, with a nearly neutral response to oak edges and the increase with distance from eucalyptus edges, probably reflected the cumulative effect of contrasting responses by steppe and other farmland birds. Difference in bird responses to pine and oak edges were relatively small, though they tended to be stronger to the former. Linnet abundance was highest near pine edges, probably because this species finds adequate breeding conditions in young umbrella pine plantations (Khoury et al., 2009), which may provide more concealment against predators than small and sparse oak plantations. The reason for short-toed larks increasing faster away from pine than oak edges was unclear.

The size of open arable patches and edge density also affected edge responses by bird functional groups and individual species, underlining the presence of interactions between edge effects and landscape fragmentation. The prevalence and magnitude of such interactions were relatively unexpected, as fragmentation had the least effect on measured responses in a recent review of interactions affecting edge effects (Ries et al., 2004). It should thus be evaluated whether such interactions may be more widespread than previously realized, using for instance sampling designs and statistical approaches similar to those adopted herein. These allowed the detection of complex interaction between edge and fragmentation effects such as that of stonechats, which showed strong positive responses to edges in landscapes dominated by large arable patches, whereas virtually neutral responses to smaller arable patches. This suggests that stonechats were largely confined to farmland fields near wooded edges in open farmland, whereas in fragmented agricultural landscapes they were more ubiquitous. A comparable pattern, albeit not as strong, was evident for the corn bunting, which showed the strongest edge responses in landscapes with low edge density.
Landscape fragmentation also affected negative edge responses, with the overall richness and abundance of steppe birds and the abundance of calandra larks increasing faster away from edges in less fragmented landscapes. These results agree with previous research carried out within the same study area, showing that the calandra lark is extremely sensitive to the fragmentation of grassland habitats, tending to occur at the highest densities in open grassland patches $>100$ ha (Morgado et al., unpublished data). They are also akin to the results of Fletcher (2005), who showed that negative edge effects on a North American grassland bird were intensified by the joint influence of multiple edges. The processes that underlie these patterns are unclear at present, but they may be related to the exacerbated influence near multiple edges of the mechanisms usually considered to affect bird responses to edges, such as behavioural aversion, changes in habitat structure, food availability and species interactions (Ries et al., 2004; Fletcher, 2005). The overall pattern for the steppe birds, however, was not evident for short-toed larks, which increased faster away from edges in landscapes with higher edge density, suggesting that although short-toed larks avoided edges, they tended to be more abundant in more fragmented landscapes. We tentatively hypothesize that interspecific competition may be involved in shaping such patterns, with much larger calandra larks being restricted to large habitat patches (Morgado et al., unpublished data; this study) and relegating short-toed larks to more fragmented landscapes. This hypothesis is based on the observation that competition may be an important driving force in community assembly of granivorous birds inhabiting simple environments (e.g., Grant and Grant, 2006), that competition appears to be a significant mechanism shaping the distribution patterns and habitat selection of Calandrella larks (Suárez et al., 2002; Serrano and Astrain, 2005), and that habitat segregation between calandra and short-toed larks has been recorded within the study area (Moreira, 1999; Delgado and Moreira, 2000).

\subsection{Conservation}

This study extends previous findings of the effects of afforestation in Mediterranean open farmland, showing that the edge effects of forest plantations may contribute to increase local bird diversity at the expense of negative effects for steppe birds of European conservation concern (Burfield and van Bommel, 2004). Although some farmland birds appeared to thrive at forest plantation edges, they were generally of less conservation concern than the open grassland specialists (Suárez et al., 1997; Burfield and van Bommel, 2004; Bota et al., 2005).

Recognizing the potential for significant negative edge effects has consequences for the impact assessment and planning of afforestation in Mediterranean farmland. In the first place, it should be duly considered that the total area affected by a forest plantation is larger than the surface actually planted with trees. Assuming purely geometric effects, plantations of, for instance 1, 10 and 100 ha, with a 200 m edge effect and a circular shape, would cause reductions in habitat area for steppe birds of about 21, 45 and 183 ha, respectively (e.g., Sisk and Haddad, 2002). The extent of such habitat reductions may further increase with the proportion of the landscape con- 
verted into forest, as the strength of negative edge effects tended to increase along with the edge density of unsuitable habitats (Fletcher, 2005; Ewers and Didham, 2007; this study). This implies that population declines of edge-avoiding species should occur more rapidly than expected from simple loss of habitat, and that such declines should be progressively faster with increasing habitat fragmentation. This supports the recommendation that afforestation in Mediterranean farmland should be avoided in areas occupied by steppe birds of conservation concern (Díaz et al., 1998).

Where afforestation is unavoidable due to political, social or economic constraints, landscape planning should strive to reduce fragmentation of adjacent agricultural habitats. A spatial configuration of forest patches minimizing edge effects may be achieved by afforesting a small number of relatively large patches, preferably those with little initial value for species of conservation concern, instead of planting several small forest patches scattered across the landscape (e.g., Sisk and Haddad, 2002). This recommendation has the double advantage of favouring the development of rich bird assemblages within forest patches (Díaz et al., 1998) and reducing the impacts on edge-avoiding steppe birds. Enforcing such recommendation in practice, however, has to meet the challenges of managing multi-ownership landscapes, where individual land-use decisions on private lands may compromise global management goals (e.g., Spies et al., 2002). Solving this problem probably requires a combination of regulatory (e.g., laws and policies restricting or governing the conversion of farmland into forest) and incentive-based approaches (e.g., agri-environment schemes increasing the economic return from agricultural land), aimed at reducing the total area and promoting the aggregation of forest planta- tions. Finding the best solution from the ecological perspective, however, calls for a better understanding of how species-specific edge effects translate into population and community responses at the landscape-scale, which is critical for predicting the amount, size and spatial configuration of suitable habitats required for the conservation of edge-sensitive species (Sisk and Haddad, 2002; Ewers and Didham, 2007).

\section{Acknowledgements}

This project was funded by the Comissão de Coordenação e Desenvolvimento Regional do Alentejo and Associação de Defesa do Património de Mértola. Luís Reino was supported by a PhD Grant (SFRH/BD/14085/2003) from the Portuguese Science Foundation (FCT). We thank Robert Ewers, Pedro Leitão and Jorge Cadima for discussions concerning the statistical analysis, and three anonymous referees for helpful comments and suggestions to improve the paper. Thanks are also due to Miguel Porto for helping to process digital photographs and Joana Santana, Luís Gordinho and Nuno Leitão for help in preparing the figures. We also thank Liga para a Protecção da Natureza for providing logistics during fieldwork.

\section{Appendix A}

Percentage occurrence in point counts, number per point count, and mean $( \pm \mathrm{SD}$ ) abundances (birds/10 ha) of birds recorded in farmland habitats around forest plantations $(<300 \mathrm{~m})$ in southern Portugal. Species were classified in four functional groups: $\mathrm{F}$ = Arable farmland birds; $\mathrm{S}$ = Steppe birds; $\mathrm{W}=$ Woodland and shrubland birds; and $\mathrm{G}=$ Ground nesting birds.

\begin{tabular}{|c|c|c|c|c|}
\hline Common name & Group & \%Occurrence $(n=208)$ & Number of birds & Mean \pm SD \\
\hline Calandra lark (Melanocorypha calandra) & $\mathrm{F}, \mathrm{S}, \mathrm{G}$ & 26.4 & 115 & $7.0 \pm 14.3$ \\
\hline Corn bunting (Emberiza calandra) & $\mathrm{F}, \mathrm{G}$ & 25.5 & 78 & $4.8 \pm 9.4$ \\
\hline Crested/Thekla larks (Galerida spp.) & F,G & 23.6 & 66 & $4.0 \pm 8.3$ \\
\hline Short-toed lark (Calandrella brachydactyla) & $\mathrm{F}, \mathrm{S}, \mathrm{G}$ & 17.8 & 53 & $3.2 \pm 8.1$ \\
\hline Goldfinch (Carduelis carduelis) & W & 10.1 & 58 & $3.6 \pm 20.4$ \\
\hline Tawny pipit (Anthus campestris) & F,S,G & 9.6 & 21 & $1.3 \pm 4.0$ \\
\hline Stonechat (Saxicola torquatus) & $\mathrm{F}, \mathrm{G}$ & 9.6 & 25 & $1.5 \pm 5.2$ \\
\hline Linnet (Carduelis cannabina) & W & 7.7 & 22 & $1.3 \pm 5.1$ \\
\hline Little bustard (Tetrax tetrax) & $\mathrm{F}, \mathrm{S}, \mathrm{G}$ & 7.6 & 20 & $1.2 \pm 4.7$ \\
\hline Red-legged partridge (Alectoris rufa) & $\mathrm{F}, \mathrm{G}$ & 5.8 & 15 & $0.9 \pm 3.9$ \\
\hline Montagu's harrier (Circus pygargus) & $\mathrm{F}, \mathrm{S}, \mathrm{G}$ & 5.3 & 11 & $0.7 \pm 2.9$ \\
\hline White stork (Ciconia ciconia) & F & 4.3 & 25 & $1.5 \pm 11.6$ \\
\hline Black-eared wheatear (Oenanthe hispanica) & $\mathrm{F}, \mathrm{S}, \mathrm{G}$ & 3.7 & 8 & $0.5 \pm 2.8$ \\
\hline Common/Spanish sparrow (Passer spp.) & W & 3.4 & 158 & $9.7 \pm 69.7$ \\
\hline Spotless starling (Sturnus unicolor) & W & 2.9 & 28 & $1.7 \pm 18.0$ \\
\hline Black kite (Milvus migrans) & $\mathrm{W}$ & 2.9 & 7 & $0.4 \pm 2.6$ \\
\hline Greenfinch (Carduelis chloris) & W & 2.9 & 6 & $0.4 \pm 2.1$ \\
\hline Azure-winged magpie (Cyanopica cyanus) & W & 2.4 & 11 & $0.7 \pm 2.4$ \\
\hline Carrion crow (Corvus corone) & $\mathrm{W}$ & 2.4 & 10 & $0.6 \pm 4.1$ \\
\hline Southern-grey shrike (Lanius meridionalis) & $\mathrm{F}$ & 2.4 & 5 & $0.3 \pm 2.0$ \\
\hline Woodchat shrike (Lanius senator) & $\mathrm{W}$ & 2.4 & 5 & $0.3 \pm 2.0$ \\
\hline Sardinian warbler (Sylvia melanocephala) & W & 1.9 & 4 & $0.2 \pm 1.8$ \\
\hline Blackbird (Turdus merula) & $\mathrm{W}$ & 1.9 & 4 & $0.2 \pm 1.8$ \\
\hline Common buzzard (Buteo buteo) & $\mathrm{W}$ & 1.9 & 7 & $0.4 \pm 3.2$ \\
\hline Hoopoe (Upupa epops) & $\mathrm{F}$ & 1.9 & 4 & $0.2 \pm 1.8$ \\
\hline Kestrel (Falco tinnunculus) & $\mathrm{F}$ & 1.4 & 3 & $0.2 \pm 1.5$ \\
\hline Serin (Serinus serinus) & $\mathrm{W}$ & 1.4 & 3 & $0.2 \pm 1.5$ \\
\hline
\end{tabular}


Appendix A (continued)

\begin{tabular}{|c|c|c|c|c|}
\hline Common name & Group & \%Occurrence $(n=208)$ & Number of birds & Mean \pm SD \\
\hline Cattle egrett (Bubulcus ibis) & $\mathrm{F}$ & 1.0 & 21 & $1.3 \pm 17.7$ \\
\hline Woodlark (Lullula arborea) & $\mathrm{F}, \mathrm{G}$ & 1.0 & 2 & $0.1 \pm 1.2$ \\
\hline Fan-tailed warbler (Cisticola juncidis) & $\mathrm{F}, \mathrm{G}$ & 1.0 & 2 & $0.1 \pm 1.2$ \\
\hline Stone curlew (Burhinus oedicnemus) & $\mathrm{F}, \mathrm{S}, \mathrm{G}$ & 1.0 & 2 & $0.1 \pm 1.2$ \\
\hline Black-bellied sandgrouse (Pterocles orientalis) & $\mathrm{F}, \mathrm{S}, \mathrm{G}$ & 1.0 & 3 & $0.2 \pm 2.0$ \\
\hline Collared pranticole (Glareola pranticola) & $\mathrm{F}, \mathrm{S}, \mathrm{G}$ & 1.0 & 2 & $0.1 \pm 1.2$ \\
\hline Red kite (Miluus miluus) & W & 1.0 & 2 & $0.1 \pm 1.2$ \\
\hline Lesser kestrel (Falco naumanni) & F,S & 1.0 & 2 & $0.1 \pm 1.2$ \\
\hline Little owl (Athene noctua) & $\mathrm{F}$ & 1.0 & 1 & $0.2 \pm 2.0$ \\
\hline Booted eagle (Hieraaetus pennatus) & $\mathrm{W}$ & 0.5 & 1 & $0.1 \pm 0.9$ \\
\hline Quail (Coturnix coturnix) & $F, G$ & 0.5 & 1 & $0.1 \pm 0.9$ \\
\hline Great bustard (Otis tarda) & $\mathrm{F}, \mathrm{S}, \mathrm{G}$ & 0.5 & 1 & $0.1 \pm 0.9$ \\
\hline Collared dove (Streptopelia decaocto) & $\mathrm{W}$ & 0.5 & 1 & $0.1 \pm 0.9$ \\
\hline Cuckoo (Cuculus canorus) & W & 0.5 & 1 & $0.1 \pm 0.9$ \\
\hline Green woodpecker (Picus viridis) & $\mathrm{W}$ & 0.5 & 1 & $0.1 \pm 0.9$ \\
\hline Blue tit (Cyanistes caeruleus) & $\mathrm{W}$ & 0.5 & 1 & $0.1 \pm 0.9$ \\
\hline Great tit (Parus major) & $\mathrm{W}$ & 0.5 & 1 & $0.1 \pm 0.9$ \\
\hline Short-toed treecreeper (Certhia brachydactyla) & W & 0.5 & 1 & $0.1 \pm 0.9$ \\
\hline Raven (Corvus corax) & $\mathrm{W}$ & 0.5 & 1 & $0.1 \pm 0.9$ \\
\hline Chaffinch (Fringilla coelebs) & $\mathrm{W}$ & 0.5 & 1 & $0.1 \pm 0.9$ \\
\hline
\end{tabular}

\section{R E F E R E N C E S}

Best, L.B., Bergin, T.M., Freemark, K.E., 2001. Influence of landscape composition on bird use of row crop fields. Journal of Wildlife Management 65, 442-449.

Betts, M.G., Forbes, G.J., Diamond, A.W., Taylor, P.D., 2006. Independent effects of fragmentation on forest songbirds: an organism-based approach. Ecological Applications 16, 1076-1089.

Bibby, C.J., Burgess, N.D., Hill, D.A., Mustoe, S.H., 2000. Bird Census Techniques, second ed. Academic Press, London.

Bollinger, E.K., Gavin, T.A., 2004. Response of nesting bobolinks (Dolichonyx oryzivorus) to habitat edges. Auk 121, 767-776.

Bota, G., Morales, M.B., Mañosa, S., Camprodon, J. (Eds.), 2005. Ecology and Conservation of Steppe-land Birds. Lynx Edicions \& Centre Tecnològic Forestal de Catalunya, Barcelona.

Brennan, L.A., Kuvlesky, W.P., 2005. North American grassland birds: an unfolding conservation crisis? Journal of Wildlife Management 69, 1-13.

Brotons, L., Wolff, A., Paulus, G., Martin, J.-L., 2005. Effects of adjacent agricultural habitat on the distribution of passerines in natural grasslands. Biological Conservation 124, 407-414.

Burfield, I., van Bommel, F., 2004. Birds in Europe: Population Estimates Trends and Conservation Status. Birdlife International, Cambridge.

Burger, L.D., Burger, L.W., Faaborg, J., 1994. Effects of prairie fragmentation and predation on artificial nests. Journal of Wildlife Management 58, 249-254.

Burnham, K.P., Anderson, D.R., 2002. Model Selection and Multimodel Inference: A Practical Information-theoretic Approach, second ed. Springer, New York.

Caparrós, A., Jacquemont, F., 2003. Conflicts between biodiversity and carbon sequestration programs: economic and legal implications. Ecological Economics 46, 143-157.

Coppedge, B.R., Engle, D.M., Masters, R.E., Gregory, M.S., 2004. Predicting juniper encroachment and CRP effects on avian community dynamics in southern mix-grass prairie, USA. Biological Conservation 115, 431-441.
Creegan, H.P., Osborne, P.E., 2005. Gap crossing decisions of woodland songbirds in Scotland: an experimental approach. Journal of Applied Ecology 42, 678-687.

Delgado, A., Moreira, F., 2000. Bird assemblages of an Iberian cereal steppe. Agriculture, Ecosystems and Environment 78, 65-76.

Díaz, M., Carbonell, R., Santos, T., Tellería, J.S., 1998. Breeding bird communities in pine plantations of the Spanish plateaux: biogeography, landscape and vegetation effects. Journal of Applied Ecology 35, 562-574.

Ewers, R.M., Didham, R.K., 2006a. Confounding factors in the detection of species responses to habitat fragmentation. Biological Reviews 81, 117-142.

Ewers, R.M., Didham, R.K., 2006b. Continuous response functions for quantifying the strength of edge effects. Journal of Applied Ecology 43, 527-536.

Ewers, R.M., Didham, R.K., 2007. The effect of fragment shape and species' sensitivity to habitat edges on animal population size. Conservation Biology 21, 926-936.

Ewers, R.M., Thorpe, S., Didham, R.K., 2007. Synergistic interactions between edge and area effects in a heavily fragmented landscape. Ecology 88, 96-106.

Fletcher Jr., R.J., 2005. Multiple edge effects and their implications in fragmented landscapes. Journal of Animal Ecology 74, 342352.

Freemark, K.E., Kirk, D.A., 2001. Birds on organic and conventional farms in Ontario: partitioning effects of habitat and practices on species composition and abundance. Biological Conservation 101, 337-350.

García-Quijano, J.F., Peters, J., Cockx, L., van Wyk, G., Rosanov, A., Deckmyn, G., Ceulemans, R., Ward, S.M., Holden, N.M., van Orshoven, J., Muys, B., 2007. Carbon sequestration and environmental effects of afforestation with Pinus radiata D. Don in the Western Cape, South Africa. Climatic Change 83, 323-355.

Grant, P.R., Grant, B.R., 2006. Evolution of character displacement in Darwin's Finches. Science 313, 224-226.

Khoury, F., Janaydeh, M., Al-Hmoud, A.R., 2009. Nest placement and nesting success in two finch species colonizing a recently established plantation in an arid region. Journal of Ornithology 150, 29-37. 
Lazdinis, M., Roberge, J.-M., Kurlavičius, P., Mozgeris, G., Angelstam, P., 2005. Afforestation planning and biodiversity conservation: predicting effects on habitat functionality in Lithuania. Journal of Environmental Planning and Management 48, 331-348.

Legendre, P., Legendre, L., 1998. Numerical Ecology, second ed. Elsevier, Amsterdam.

López, G., Moro, M.J., 1997. Birds of Aleppo pine plantations in south-east Spain in relation to vegetation composition and structure. Journal of Applied Ecology 33, 243-262.

Loyn, R.H., McNabb, E.G., Macak, P., Noble, P., 2007. Eucalypt plantations as habitat for birds on previously cleared farmland in south-eastern Australia. Biological Conservation 137, 533-548.

Lukacs, P.M., Thompson, W.L., Kendall, W.L., Gould, W.R., Doherty Jr, P.F., Burnham, K.P., Anderson, D.R., 2007. Concerns regarding a call for pluralism of information theory and hypothesis testing. Journal of Applied Ecology 44, 456-460.

Madsen, L.M., 2002. The Danish afforestation programme and spatial planning: new challenges. Landscape and Urban Planning 58, 241-254.

Matthews, S., O'Connor, R., Plantinga, A.J., 2002. Quantifying the impacts on biodiversity of policies for carbon sequestration in forests. Ecological Economics 40, 71-87.

Moreira, F., 1999. Relationships between vegetation structure and breeding bird densities in fallow cereal steppes in Castro Verde, Portugal. Bird Study 46, 309-318.

Moreira, F., Beja, P., Morgado, R., Reino, L., Gordinho, L., Delgado, A., Borralho, R., 2005. Effects of field management and landscape context on grassland wintering birds in Southern Portugal. Agriculture, Ecosystems and Environment 109, 59-74.

Pinheiro, J.C., Bates, D.M., 2000. Mixed-efffects Models in S and S-Plus. Springer, New York.

Pinheiro, J.C., Bates, D.M., DebRoy, S., D. Sarkar, D., 2007. NLME: Linear and Nonlinear Mixed Effects Models. R Package Version 3.1-83. <http://www.R-project.org>.

Potter, C., Klooster, S., Hiatt, S., Fladeland, M., Genovese, V., Gross, V., 2007. Satellite-derived estimates of potential carbon sequestration through afforestation of agricultural lands in the United States. Climatic Change 80, 323-336.

R Development Core Team, 2008. R: A Language and Environment for Statistical Computing. R Foundation for Statistical Computing, Vienna, Austria. URL: <http://www.R-project.org>.

Rempel, R.S., Carr., A.P., 2003. Patch Analyst extension for ArcView: version 3. <http://flash.lakeheadu.ca/ rrempel/ patch/index.html $>$.

Renfrew, R.B., Ribic, C.A., Nack, J.L., 2005. Edge avoidance by nesting grassland birds: a futile strategy in a fragmented landscape. Auk 122, 618-636.

Richards, S.A., 2008. Dealing with overdispersed count data in applied ecology. Journal of Applied Ecology 45, 218-227.

Ries, L., Fletcher Jr., R.J., Battin, J., Sisk, T.D., 2004. Ecological responses to habitat edges: mechanisms, models, and variability explained. Annual Review of Ecology and Systematics 35, 491-522.

Robson, N., 1997. The evolution of the common agricultural policy and the incorporation of environmental considerations. In:
Pain, D.J., Pienkowski, M.W. (Eds.), Farming and Birds in Europe. Academic Press, London, pp. 43-78.

Santos, T., Tellería, J.L., Dias, M., Carbonell, R., 2006. Evaluating the benefits of CAP reforms: can afforestations restore bird diversity in mediterranean Spain? Basic and Applied Ecology 7, 483-495.

Serrano, D., Astrain, C., 2005. Microhabitat use and segregation of two sibling species of Calandrella larks during the breeding season: conservation and management strategies. Biological Conservation 125, 391-397.

Shochat, E., Abramsky, Z., Pinshow, B., 2001. Breeding bird species diversity in the Negev: effects of scrub fragmentation by planted forests. Journal of Applied Ecology 38, 1135-1147.

Sisk, T.D., Haddad, N.M., 2002. Incorporating the effects of habitat edges into landscape models: effective area models for crossboundary management. In: Liu, J., Taylor, W.W. (Eds.), Integrating Landscape Ecology into Natural Resource Management. Cambridge University Press, Cambridge, pp. 208-240.

Söderström, B., Pärt, T., 2000. Influence of landscape scale on farmland birds breeding in semi-natural pastures. Conservation Biology 14, 522-533.

Spies, T.A., Reeves, G.H., Burnett, K.M., McComb, W.C., Johnson, K.N., Grant, G., Ohmann, J.L., Garman, S.L., Bettinger, P., 2002. Assessing the ecological consequences of forest policies in a multi-ownership province in oregon. In: Liu, J., Taylor, W.W. (Eds.), Integrating Landscape Ecology into Natural Resource Management. Cambridge University Press, Cambridge, pp. 179-207.

Statsoft Inc., 2008. STATISTICA (data analysis software system), version 8.0. <http://www.statsoft.com>.

Stephens, P.A., Buskirk, S.W., Hayward, G.D., Martínez del Rio, C., 2005. Information theory and hypothesis testing: a call for pluralism. Journal of Applied Ecology 42, 4-12.

Suárez, F., Naveso, M.A., De Juana, E., 1997. Farming in the drylands of Spain: birds of the pseudosteppes. In: Pain, D.J., Pienkowsky, M.W. (Eds.), Farming and Birds in Europe: The Common Agricultural Policy and Its Implications for Bird Conservation. Academic Press, London, pp. 297-330.

Suárez, F., Garza, V., Morales, M.B., 2002. Habitat use of two sibling species, the short-toed Calandrella brachydactyla and the lesser short-toed C. rufescens larks, in mainland Spain. Ardeola 49, 259-272.

Van Doorn, A.M., Bakker, M.M., 2007. The destination of arable land in a marginal agricultural landscape in South Portugal: an exploration of land use change determinants. Landscape Ecology 22, 1073-1087.

Vickery, P.C., Hunter, M.L., Wells, J.V., 1992. Evidence of incidental nest predation and its effects on nests of threatened grassland birds. Oikos 63, 281-288.

Yanes, M., Herranz, J., Suárez, F., 1996. Nest microhabitat selection in larks from a European semi-arid shrub-steppe: the role of sunlight and predation. Journal of Arid Environments 32, 469478.

Zar, J.H., 1996. Biostatistical Analysis, 3rd ed. Prentice Hall, New Jersey. 